\title{
Význam pomáhajících profesionálů z pohledu vývoje ekonomických teorií Jaroslav Šetek
}

\begin{abstract}
Abstrakt:
V rozvinutých tržních ekonomikách akceleruje význam terciární a kvartérní sféry oproti primární a sekundární. Jednoznačně o tom svědčí údaje makroekonomických ukazatelů, jako je prvenství v podílu služeb na hrubém domácím produktu a zaměstnanosti v ekonomice. Nedílnou součástí sektoru služeb jsou také pomáhající profese pro zájmové skupiny obyvatelstva. Podle původních teoretických konceptů klasiků ekonomické teorie Adama Smithe a Karla Marxe nejsou tyto profese pro svoji „neproduktivní práci“ tvůrci bohatství společnosti, a tudíž jsou považovány za méněcenné. Realita je však zcela jiná. Zejména teorie systémové dynamiky a synergetického efektu potvrdí, jak tyto profese přispívají k růstu kvality života všech členů společnosti. Ta jako složka lidského kapitálu představuje jeden ze zdrojů stabilního ekonomického růstu.
\end{abstract}

\section{Klíčová slova:}

pomáhající profesionál, terciární a kvartérní sféra ekonomiky, lidský a sociální kapitál, ekonomický růst

\section{Úvod}

Dělba práce, spočívající především v kvalitativní diferenciaci jednotlivých prací, představuje objektivní základ nutné výměny výsledků těchto různých konkrétních prací mezi jednotlivými členy nebo složkami společnosti. Tyto vztahy výměny výsledků činnosti spojují jednotlivé práce navzájem a vtiskují každé dílčí práci její význam ve společnosti. Důsledkem dělby práce je specializovaný producent nucen vyrábět pro ostatní členy společnosti a naopak. Tak se vytvořily specializované profese a každá má své specifické postavení v rámci ekonomiky.

Ekonomie, jako samostatná věda konstituována od 2. poloviny 18. století, se zaměřuje na tvorbu a rozdělování bohatství společnosti, jehož pojetí nebylo od samého počátku ekonomické vědy jednoznačné. To vyplývá z mnoha podob a disciplín ekonomické teorie, přičemž každá má vymezený předmět svého zkoumání, a tím i svůj obsah. ${ }^{1}$ Odpověd' na otázku, co zahrnuje ekonomická teorie, není jedna. Konkrétně dějiny ekonomického myšlení, které se zabývají vývojem ekonomie v čase, potvrzují existenci řady proudů, „škol“ a směrů, které jsou ve svých východiscích, a to 
i ve vymezení předmětu zkoumání, často až protichůdné. ${ }^{2}$ To lze spatřovat právě na př́kladu pomáhajících profesí (profesní skupiny lékařů a zdravotního personálu, sociálních pracovníků, pracovníků v sociálních službách, pedagogů apod.). Všechny tyto profese lze jednoznačně začlenit do terciární sféry ekonomiky, popřípadě některé i do sféry kvartérního sektoru, což je odvětví znalostí, které zahrnuje oblasti vědy, výzkumu, vzdělávání a informačních technologií.

$\mathrm{Na}$ základě analýzy ekonomického myšlení, formovaného od 2. poloviny 17. století až do svého osamostatnění v rámci společenských věd v 18. století, lze vyvodit značnou „degradaci“ veškerých profesí terciární sféry národního hospodářství, tedy i pomáhajících profesí. Naproti tomu realita v rozvinutých tržních ekonomikách je zcela jiná. To dokládá mj. statistika významných makroekonomických ukazatelů, jako je růst podílu sektorů služeb na hrubém domácím produktu a celkové zaměstnanosti $\mathrm{v}$ ekonomice. $\mathrm{V}$ rámci sektoru služeb rovněž roste zaměstnanost $\mathrm{v}$ oborech zaměřených na dimenzi lidského činitele. $\mathrm{K}$ tomu přispívají i pomáhající profese. Na významu budou zejména s aktuální prognózou demografického vývoje stárnutí populace nabývat pomáhající profese v oblasti gerontologie.

V souvislosti s nástupem éry Průmyslu 4.0 se na patřičné změny vznikající v důsledku inovačních trendů orientují i společenské a humanitní vědy. Jejich interdisciplinární provázanost s technickými obory se odráží i v kvalitě služeb pomáhajících profesí. To se projevuje jako výsledek realizované sociální politiky na úrovni státu, sídel, měst, regionů a občanské společnosti. Důsledkem jejího nastavení dochází ke značnému urychlení komplexního pohledu na vytvoření kvalitní infrastruktury pro lidský život všech skupin obyvatelstva. Lze tedy konstatovat, že ekonomický rozvoj provázený růstem kvality života obyvatelstva potřebuje redukovat nežádoucí jevy v masovém měřítku. K tomu výrazně přispívají pomáhající profesionálové.

Z výše uvedených důvodů je cílem článku mezioborovým přístupem zejména ekonomické teorie, filozofie a sociologie s nástinem vazby reflexí na křestanskou antropologii podat výklad pojetí podstaty, geneze a pozice pomáhajících profesí v rámci mechanismu fungování tržní ekonomiky. Dalším cílem článku je následně na základě patřičných prognóz demografického vývoje obyvatelstva (jeho stárnutí) na př́kladu České republiky, provázaného vlivem nástupu Technologií 4.0, přednést argumenty o narůstajícím početním trendu těchto profesí za účelem řešení tíživých situací jedinců důsledkem patologických sociálních událostí (onemocnění, invalidita, nezaměstnanost, závislosti, ztráta soběstačnosti, chudoba, sociální vyloučení apod.).

\section{Pozice pomáhajících profesí a jejich výkon v rámci ekonomilky}

Ze všeho nejdůležitější je objasnit, koho vlastně za pomáhající profesi považovat. Nebot' přesná definice schází, natož aby byla obecně přijata či alespoň okrajově zakotvena v některém z normativních aktů. Proto se dosud různí nejenom diskusní názory, ale i řada počinů praktického obsahu. Tím, že není zřejmé, kým se pomáhající profesionál míní, zůstává podvázána i systemizace práce s ním a péče o něj. Podle ekonomické teorie je za profesionála, a to včetně pomáhajícího, považován ten, kdo splňuje dva hlavní znaky:

1) úroveň práce daná profesionalitou projevující se v odborné způsobilosti i výkonnosti;

2) práce za úplatu konaná s charakterem povolání. ${ }^{3}$

2 Srov. Robert HOLMAN a kol., Dějiny ekonomického myšlení, 4. vydání, Praha: C. H. Beck, 2008, s. 17.

3 Srov. Vladimír BUREŠ, Řízení intelektuálního kapitálu, E+M Ekonomie a Management 3/2003, s. 77. 
Má-li se profesionál odlišovat od amatéra, musí zjevně splňovat oba znaky, rozhodně nestačí pouze jeden z nich. Pro amatéra může být př́íznačná nanejvýš složka profesionálního projevu, kdežto profesionál jen ve smyslu zaměstnaneckého vztahu, ale bez patřičné erudice, nasazení a zdaru se sám degraduje na amatéra. ${ }^{4}$ Pomáhající profesionál je tedy jedinec, který si zvolil své pracovní uplatnění v některých „vznešených profesích“, jako je psycholog, lékařr, sociální pracovník, pracovník v sociálních službách, a všude tam, kde je umění pomáhat druhým v jejich tíživé situaci. ${ }^{5}$ Při měření produktivity práce se posuzuje to, co je jednotkou práce. ${ }^{6} \mathrm{~V}$ případě pomáhajících profesí (stejně jako celého terciárního a kvartérního sektoru) se považuje za jednotku ta práce, která je provedena člověkem (živá práce) a je měřena cenou práce, čímž je mzda. Důležitým ukazatelem mzdové úrovně a postavení dané profese ve struktuře společnosti je porovnání s průměrnou nebo mediánovou mzdou v ekonomice národního hospodářství. Podle statistických ukazatelů se v České republice terciární sektor podílí aktuálně více jak 60 \% na tvorbě hrubého domácího produktu (čemuž zhruba odpovídá i zaměstnanost v tomto sektoru $-58,3 \%$ ). ${ }^{7} \mathrm{Na}$ straně druhé v roce 2017 činila průměrná mzda sociálních pracovníků 20514 Kč, pracovníků sociálních služeb 23878,4 Kč, což je v obou př́padech značně pod průměrnou mzdou české ekonomiky v tomto roce, která činila $29504 \mathrm{Kč.} .{ }^{8} \mathrm{~V}$ této souvislosti při analýze ocenění pomáhajících profesí na trhu práce lze hledat odpovědi na dvě níže uvedené otázky:

1) Jaké jsou příčiny nižšího ocenění pomáhajících profesí na trhu práce $\mathrm{v}$ současných podmínkách?

2) V čem spočívá podstata motivu působit jako pomáhající profesionál i za situace nižšího ocenění?

Odpověd’ na první otázku vychází z reality pozice pomáhajících profesí, které představují „zájmovou skupinu“. Ta může představovat ve společnosti z pohledu teorie veřejné volby (mezioborový vztah ekonomie a politologie) skupinu s malou vyjednávací silou, což však není jednoznačně dáno kvantitativním aspektem, tj. podílem počtu pomáhajících profesí na celkové zaměstnanosti v ekonomice. Např́klad v České republice je podíl zaměstnanosti v sociální péči $7 \%$, což je více oproti jiným službám (např. cestovní ruch činí 4,7\%). ${ }^{10}$ Jedna z hlavních prríčin spočívá v deontologických aspektech (profesních povinnostech) ve vazbách na reflexi křestanské antropologie při pomoci bližnímu. Ten představuje klienta sociální péče, jemuž je ze strany pomáhajících profesionálů asistováno při znovunalezení a udržení kvality důstojného života $v$ tíživých situacích. $Z$ toho důvodu se tato kategorie pracovníkủ neúčastní jako aktér žádných nátlakových akcí, jako je např. stávka, na podporu požadavků vyššího finančního ohodnocení.

Odpovědi na druhou otázku lze nalézt v některých teoretických konceptech personálního managementu a marketingu z období přelomu 20. a 21. století, které jsou doloženy empirickými výzkumy z oblasti zaměstnanosti, firemní kultury a mezilidských vztahů. Potvrdily, že hlavním motivem

\footnotetext{
Srov. Tamtéž, s. 82.

Srov. Ivan ÚLEHLA, Umění pomáhat: Učebnice metod sociální praxe, 2. vyd., Praha: Slon, 2005, s. 25.

Srov. Eva KISLINGEROVÁ a kol., Inovace nástrojů ekonomiky a managementu organizací, 1. vyd., Praha: C. H. Beck, 2008 , s. 43.

Srov. Tomáš VOLEK - Martina NOVOTNÁ, Gross value added and total factor productivity in Czech sectors, Contemporary Economics $1 / 2015$, s. $17-28$.

Srov. Statistická ročenka České republiky 2018, Český statický úřad, 2018, s. 300-302.

Srov. Dennis MUELLER, Public choice III., 1st ed., Cambridge: Cambridge University Press, 2003, xix, s. 768.

10 Srov. Statistická ročenka České republiky 2018, Český statický úřad, 2018, s. 143.
} 
není prioritně finanční ohodnocení pracovníka, ale patřičná kvalita příznivých mezilidských vztahů u zaměstnavatele a jeho systémového okolí. Paralelně počátkem 21. století presentuje L. Bruni zevrubný vztah finančních př́ijmů a subjektivního pocitu štěstí11 jako kritický bod, po jehož překročení se vztah „peníze - štěsti“" obrací. ${ }^{12} \mathrm{~V}$ duchu interpretace tohoto teoretického konceptu má být nižší úroveň finanční odměny jakýmsi „sítem“ při selekci vstupu na pracovní pozici pomáhající profese, nebot ta jako „Vznešená“ je současně „posláním“. Tudíž se o ni mají ucházet jedinci s vnitřní motivací. Ta je předmětem zájmu teoretického konceptu osobní motivace jako integrální součásti teorie sociálního kapitálu ${ }^{13}$, ke které se v rámci soudobé nové školy řadí $B$. Frey. Jeho koncept „ekonomie štěstî" ${ }^{14}$ se orientuje na vztahy bohatství a spokojenosti (interdisciplinární prolínání ekonomie s psychologií). Tímto přístupem sleduje, do jaké míry činí bohatství jedince štastným, a do jaké míry jsou to jiné záležitosti, jako je například pomoc druhým v jejich tíživé situaci.

Za zvláštní skupinu pomáhajících profesí lze považovat dobrovolníky v sociálních a zdravotních službách, a to jako formu lidské solidarity a sounáležitosti bez nároku na finanční odměnu formou mzdy. Úloha dobrovolníků $\mathrm{v}$ dnešních službách je podpůrná ${ }^{15}$, dobrovolníci doplňují práci profesionálů, zvyšují kvalitu života klientů sociálních a zdravotních služeb. Přestože činnost dobrovolníků má svoji oprávněnou pozici i v moderních sociálních a zdravotních službách (zejména pobytových), provoz těchto služeb by neměl být postaven výhradně na ní. Obdobně tomu tak bylo i u vykonavatelů civilní služby („civilkářư “), která představovala náhradu za vojenskou službu, kterou vykonával občan České republiky podléhající služební povinnosti podle legislativních norem ${ }^{16}$ (od roku 1993 do konce roku 2004 - zrušení povinné vojenské služby) ${ }^{17}$, pokud odmítl z důvodů svědomí či náboženského vyznání vykonávat základní vojenskou službu. Značná část vykonavatelů působila jako pomocná síla ve zdravotních a sociálních službách.

U výše zmíněných skupin dobrovolníků a bývalých „civilkářư se lze z pohledu ekonomické teorie zamyslet nad otázkou, zda jejich činnost je měřitelná v souladu s konceptem produktivity práce. Jelikož za jejich práci nenáleží mzda, není jejich výkon zanesen do makroekonomických ukazatelů výkonnosti ekonomiky, jako je hrubý domácí produkt. Na straně druhé statistici vyčíslují roční hodnotu práce dobrovolníků (v roce 2018 dosáhla cca 6,41 mld. Kč). ${ }^{18} \mathrm{~K}$ vyčíslení používají výši průměrné mzdy podle odvětví jejich působnosti, pokud by se jednalo o pomáhající profese, berou se v úvahu zejména odvětví zdravotnictví a sociálních služeb.

\section{Primární analýza a komparace teoretických konceptů pomáhajících profesionálli̊}

Při hledání podstaty podprůměrného ohodnocení některých pomáhajících profesionálů na trhu práce je nezbytná geneze tohoto problému. Ten se „jako červená nit“" vine již od osamostatnění ekonomické vědy s nástupem první průmyslové revoluce a moderního - industriálního typu společnosti. V tom také spočívá výzva $\mathrm{k}$ analýze konceptů ekonomického myšlení, které se formovaly od tohoto období. Ekonomické myšlenkové proudy, směry a „školy“ se od

\footnotetext{
Srov. Luigino BRUNI, Cena nezištnosti, Bratislava: Veda, 2013, s. 190.

Srov. Lubomír MLČOCH, Ekonomie Duvěry a společenského dobra, Praha: Karolinum, 2005, s. 140.

Srov. Jiří HLAVÁČEK a kol., Mikroekonomie sounáležitosti se společenstvím, Praha: Karolinum, 1999, s. 26.

Bruno FREY - Alois STUTZER, Happiness, Economy and Institutions, The Economic Journal 466/2000, s. 918-938.

Srov. Zákon č. 198/2002 Sb., o dobrovolnické službě.

Srov. Zákon č. 18/1992 Sb., o civilní službě.

Srov. Zákon č. 587/2004 Sb., o zrušení civilní služby.

8 Srov. Statistická ročenka České republiky 2018, Český statický úřad, 2018, s. 298.
} 
samého počátku vyvíjí převážně evoluční cestou. ${ }^{19}$ Evoluci lze snadno vystopovat $\mathrm{v}$ jednotlivých směrech či školách, které jsou provázány jako teoretické systémy. Posun ekonomického myšlení se uskutečňuje nahrazením jednoho směru jiným směrem. Tím se mění i způsob řešení zkoumaných otázek. Mění se paradigma, tzn. daný přístup a soustava poznatků využívaných ve vědecké analýze hlavního proudu. $V$ př́slušném časovém období jsou tyto př́istupy a poznatky zpř́stupňovány a pozice přijatého paradigmatu teorie se snaží odhalovat a analyzovat problémy ekonomiky národního hospodářství jako celku, ale i jeho součástí - odvětví, sektorů a úsekủ. ${ }^{20}$ Přitom se lze setkat $s$ prrípady, které jsou $\mathrm{z}$ těchto pozic nevysvětlitelné. Právě existence takových anomálii vede $\mathrm{k}$ hledání nových př́istupů, na jejichž základě vzniká nové paradigma a jeho stoupenci odmítnou paradigma hlavního proudu. ${ }^{21}$ Pozice pomáhajících profesionálů v ekonomice je typický učebnicový př́klad. Ve své podstatě se jedná o součást terciární či kvartérní sféry ekonomiky. Ta je považována od samého počátku podle kontextu ekonomické teorie klasiků Adama Smithe a Karla Marxe za část „nevýrobní - neproduktivní sféry“. Východiskem pro analýzu je pojetí lidské práce. Zájem o ni lze spatřovat snad již od antického myšlení, a to s jejím členěním na fyzickou a duševní, kvalifikovanou a nekvalifikovanou.

Zhruba od nástupu vědecké revoluce (časově od 16. století), jejíz základy položil Mikuláš Koperník, se lze setkávat s členěním práce na produktivní a neproduktivní. S tímto dvojakým členěním se hledají odpovědi na otázku: Co je zdrojem bohatství národa? Odpověd’ na otázku není jednoznačná, diferencuje se podle jednotlivých konceptů ekonomického myšlení. Již teoretický proud merkantilistů, který v oblasti evropského ekonomického myšlení převládal v časovém rozmezí od vědecké revoluce $\mathrm{k}$ průmyslové, zastával tvrzení, že zdroj národního bohatství představuje zahraniční obchod. Proto práce v tomto odvětví je považována za produktivní. Naproti tomu ekonomické myšlení fyziokratů, které bylo založeno na myšlence "přirozeného řádu“ a "přirozeného práva“, považovalo př́rodu i společnost za organismus, který je ovládán „přirozenými zákony“. Proto jejich koncept o „zemědělském královstvi“ označuje za zdroj bohatství zemědělskou výrobu a za produktivní považují pouze práci v zemědělství. ${ }^{22}$ Podle nich tedy půda ve spojení s prací představuje jediný produktivní faktor bohatství země. Významná osobnost formativní ekonomické teorie Angličan William Petty, považovaný za prvního statistika, ve svém významném díle Politická aritmetika z roku 1678 předkládá konfrontaci politických a ekonomických argumentů s empirickými daty. V této souvislosti lze poukázat na Pettyho metodu kvantifikace, což znamená určení kvantity určité kvality za použití čísel. ${ }^{23}$ Jedná se o postup založený na přriřazení kvantitativního symbolu $\mathrm{k}$ nějaké kvalitě. Při aplikaci této metody považoval práci námořníka za $3 \mathrm{krát}$ produktivnější ve srovnání s prací zemědělce.

\section{Koncept dvojakého charakteru práce podle A. Smithe pro pojetí pomáhajících profesí}

Základem ekonomického života je snaha zpř́ijemnit si život. V této snaze naráží člověk na omezenost zdrojů, které mu poskytuje okolí. Proto se od nepaměti zabývá ekonomickými úvahami, které spočívají v odpovědi na základní tři otázky ekonomie - „co vyrábět, jak vyrábět, pro koho

19 Srov. Paul HEYNE, Ekonomický styl myšlení, Praha: Vysoká škola ekonomická, 1991, s. 146-150.

20 Srov. tamtéž, s. 158.

21 Srov. tamtéž, s. 163.

22 Srov. tamtéž, s. 182.

23 Srov. HOLMAN a kol., Dějiny..., s. 17. 
vyrábět “24 Tyto základní otázky, jinak nazývané Samuelsonova triáda, vytváří na první pohled dojem, že ekonomie se zabývá pouze činnostmi spojenými s produkcí materiálních statků a služeb. Jak již bylo naznačeno, při vzniku samostatné ekonomické teorie tomu tak bylo, nebở veškeré vyrobené hmotné statky představovaly bohatství společnosti. Zastáncem tohoto teoretického konceptu je duchovní otec ekonomické teorie skotský filozof Adam Smith. Ten se nejprve zabýval zcela jiným oborem - morální filozofií. V té považoval za základní lidské vlastnosti solidaritu a dobročinnost, od kterých se také odvozuje uspořádání společnosti. ${ }^{25}$ To dokresluje mj. i jeho významné dílo Teorie mravních citů, kde spatřuje základ veškeré etiky v sociálním citu a hlas svědomí je podle něho ozvěnou toho, jak o nás soudí jiní. ${ }^{26}$

Zásadní zvrat nastává u A. Smithe v roce 1776, kdy vydává své dílo Pojednání o podstatě a původu bohatství národů, které se stalo přelomovým ve vývoji ekonomické vědy. Tímto letopočtem se také datuje osamostatnění ekonomie v rámci společenských věd a A. Smith je považován za zakladatele - „duchovního otce“ ekonomie. Avšak na rozdíl od pozice morální filozofie toto dílo ustavilo za východisko sledování vlastního individuálního prospěchu. Z etického pohledu lze tedy na A. Smithe nahlížet jako na „morálního filozofa“ a „nemorálního“ ekonoma.

V rámci Smithova konceptu ekonomického myšlení představuje lidská práce, její dělba a produktivita základní kategorii tržního hospodářství a jeho rozvoje. ${ }^{27}$ Jestliže výsledkem práce jsou hmotné statky schopné uspokojovat lidské potřeby, jedná se podle jeho konceptu pouze o produktivní práci (na rozdíl od fyziokratů nejen v zemědělství, ale také v průmyslu, resp. řemeslu), tedy o práci v primárním a sekundárním sektoru ekonomiky. Neproduktivní práce byla pro něj spojená s poskytováním nehmotné služby, spadá tedy do terciálního sektoru. ${ }^{28}$ Podle stanovené funkce produktivní práce následně charakterizuje za rozhodující činitel ekonomického růstu bohatství dělbu práce při výrobě hmotných statků coby zdroje bohatství. Ve stejném duchu se také nese jeho teoretický koncept pracovní teorie hodnoty. Podle ní hodnota vyrobeného hmotného statku se skládá ze dvou složek, které prezentují práce zvěcnělá (minulá mrtvá) a současná (živá). První složku v podobě staré hodnoty představuje práce zvěcnělá, kdy se jedná o spotřebované předměty a opotřebení (amortizaci) zařízení. Druhou složku - práci současnou (živou) - představuje nová hodnota. Vycházel přitom z toho, že celkový fond práce je ve společnosti dán, ale nepředstavuje barieru jednoznačně omezující velikost produktu, ten závisí na tom, jak produktivně bude práce vynaložena, a dělba práce je faktorem ovlivňujícím produktivitu práce. Produktivita práce roste především v důsledku těchto faktorů, kterými jsou růst zručnosti a pracovních dovedností, organizace vynakládání práce a zdokonalení nástrojů pro jejich přizpůsobování pracovním úkonům. ${ }^{29}$

Na základě metody indukce a induktivního vyvozování lze po analýze teoretického konceptu A. Smithe jednoznačně dospět k výkladu pozice pomáhajících profesionálů v rámci ekonomiky národního hospodářství. Zde jednoznačně vykonávají neproduktivní práci v tzv. nevýrobní sféře, a proto jejich profese je ve společnosti považována za méněcennou.

24 Paul SAMUELSON - William NORDHAUS, Ekonomie, Praha: Svoboda, 1991, s. 24

25 Srov. Adam SMITH, Teorie mravních citư, Praha: Liberální institut, 2005, s. 272.

26 Srov. tamtéž, s. 303-305.

27 Srov. Adam SMITH, Pojednání o podstatě a pưvodu bohatství národů, Praha: Liberální institut, 2001, s. 293.

28 Srov. tamtéž, s. 204.

29 Srov. tamtéž, s. 329-341. 


\section{Koncept „širšího“ dvojakého charakteru práce podle K. Marxe pro pojetí pomáhajících profesí}

Německý filosof, sociolog, historik a ekonom K. Marx se původně jako A. Smith věnoval filosofii. Společně s Friedrichem Engelsem sestavil v roce 1845 koncept materialistické interpretace německé klasické filosofie a dialektický a historický materialismus. Přechod k ekonomické problematice u Marxe a Engelse lze datovat do let 1857-1859, kdy byly vydány Rukopisy Grundrisse (1857-1858) a spis Ke kritice politické ekonomie (1859). S cílem fundamentální analýzy kapitalismu koncipuje Marx Kapitál. Stěžejní první díl vychází za jeho života (1867), druhý (1885) a třetí (1894) byly dopracované Engelsem, čtvrtý (Teorie o nadhodnotě) byl poté upraven K. Kautským $\mathrm{v}$ roce 1904.

V Kapitálu Marx začíná zkoumáním zboží, které má užitnou hodnotu (výsledek práce konkrétní, povahy soukromé) a směnnou hodnotu (výsledek bezrozměrné práce vůbec - práce abstraktní, povahy společenské) ${ }^{30} \mathrm{~V}$ návaznosti na předchůdce (počínaje ekvivalencí směny $\mathrm{u}$ Aristotela) rozpracovává teorii pracovní hodnoty. Hodnotu chápe jako společenskou kategorii vznikající abstraktní prací, určovanou množstvím společensky nutné pracovní doby vynaložené na výrobu zboží (se zohledněním průměrných podmínek). Hodnota se zde nemůže projevovat $\mathrm{v}$ užitné hodnotě, ale pouze ve vzájemném vztahu zboží jako směnné hodnoty. Směna zboží vyjadřuje spojení mezi výrobci prostřednictvím trhu. Tam, kde jiná ekonomie vidí vztah mezi věcmi (směnu zboží za zboží), charakterizuje Marx vztah mezi lidmi. ${ }^{31}$ Propojení umocňují peníze a kapitál, kdy se zbožím stává lidská pracovní síla. Působí zákon hodnoty - směna zboží se uskutečňuje podle hodnot (podle množství práce ztělesněné ve zboží). Podle marxistického konceptu je hodnota zboží dána kapitálovými složkami na koupi výrobních prostředků (konstantní kapitál) a na koupi pracovní síly (variabilní kapitál). Tyto kapitálové složky hodnoty jsou téměř identické s pojetím hodnoty již zmíněného A. Smithe. Podle Marxe je navíc v hodnotě zboží obsažena složka nadhodnoty, která se jako zdroj „vykořistování stala hlavním předmětem zájmu marxistické ekonomické teorie. $\mathrm{V}$ ostatních ekonomických teorií se považuje pouze za ideologický blud, tedy "pohádku o kapitalismu“. ${ }^{32}$ Podle Marxe je nadhodnota plodem pouze variabilního kapitálu (který je schopný zvyšovat hodnotu). Z toho tedy vyplývá Marxův fenomén dvojakého charakteru práce (avšak pouze produktivní), a to práce konkrétní a abstraktní: konkrétní přenáší hodnotu spotřebovaných výrobních prostředků, abstraktní práce současně tvoří novou hodnotu (představuje variabilní kapitál a nadhodnotu). ${ }^{33}$

Prostřednictvím identické metody jako u A. Smithe lze rovněž vyvodit analytické závěry $k$ teoretickému konceptu K. Marxe. Ten byl zásadním kritikem a odpưrcem A. Smithe, nicméně se dá jednoznačně konstatovat, že měli téměř totožné názory na pojetí práce produktivní i neproduktivní. Pojetí lidské práce je u K. Marxe širší, zvláště u práce produktivní, čímž směřuje $\mathrm{k}$ výkladu teorie nadhodnoty. Stejně jako u A. Smithe lze rovněž vydedukovat jeho „degradaci“ pomáhajících profesionálů ve společnosti. Tito profesionálové by podle Marxova interdisciplinárního prŕstupu ekonomie, filozofie a sociologie představovali pouhé „zachránce“ zájmů buržoazie před revolucí směřující k odstranění vykořistování, jehož zdrojem je zmíněná existence nadhodnoty. Rovněž o tom svědčí i jeho ideologie namířená proti sociální doktríně a charitativní aktivitě církve, ze které se rovněž formovaly specializované pomáhající profese pro potřebné.

30 Srov. Karel MARX, Ke kritice politické ekonomie, Praha: Státní nakladatelství politické literatury, 1953, s. 7.

31 Srov. Karel MARX, Kapitál I, Praha: Svoboda, 1978, s. 62.

32 Joan Violet ROBINSON, The Collected Economic Papers, Oxford: Oxford University Press, 1964, s. 7-9.

33 Srov. MARX, Kapitál..., s. 62. 


\section{Jean Baptist Say - teoretický koncept jako zásadní obrat v ekonomické teorii pro poznání významu pomáhajících profesí}

Předmětem zájmu jak A. Smithe, tak K. Marxe byla lidská práce. Oproti A. Smithovi ji Marx pojal jako základní prvek pracovního procesu, ovšem pouze při výrobě hmotných statků, nebot jeho styl ekonomického myšlení byl pouze v dimenzích materiální výroby. V této souvislosti představovala lidská práce společně s pracovními předměty a prostředky základní tři prvky pracovního procesu, pro něž zavedl pojem jednoduché momenty pracovního procesu. ${ }^{34}$ Lze tedy konstatovat, že od nástupu první průmyslové revoluce se lidská práce při hmotné výrobě stala předmětem analýz, započatých A. Smithem a pokračujících v díle K. Marxe.

V období let 1803-1817 (více jak 30 let před prezentací Marxova ekonomického modelu) byla francouzským klasickým ekonomem J. B. Sayem specifikována hodnota prostřednictvím teorie tř́i výrobních faktorů, a to v dílech Pojednání o politické ekonomii (z roku 1803) a Katechismus politické ekonomie (z roku 1817). Tato díla položila základ k chápání významu práce ve všech sektorech ekonomiky - tedy primárním, sekundárním a terciárním. J. B. Say navázal sice i na A. Smithe, avšak s řadou specifik a odlišností. Ty lze spatřovat v budoucím významu orientace ekonomické vědy na užitečnost, v tomto kontextu byla zahrnuta i hodnota výrobku. Výrobu J. B. Say specifikuje ve smyslu výroby užitečností, proto zásadně odmítá verzi i pracovní teorie hodnoty podle A. Smithe.

Teoretickým konceptem J. B. Saye nastává v ekonomické teorii historický mezník, jímž se stala mikroteorie produktivnosti všech výrobních faktorů, kterými jsou práce, kapitál a půda. Tyto zmíněné faktory mají alternativní použití, tzn. univerzální využití ve všech sektorech, odvětvích a profesích. Avšak z důvodu jejich omezenosti je nelze využít najednou. Tento historický mezník otevřel prostor pro výklad teorie práce bez ohledu na sektory, odvětví a profese. Veškerá práce v ekonomice při výrobě hmotných statků a poskytování služeb nehmotné povahy poskytuje bohatství společnosti. To dokládají mimo jiné i makroekonomické teorie od 30. let 20. století $\mathrm{v}$ rámci konceptů agregátní poptávky a statistiky národního účetnictví pro výpočet hrubého domácího produktu národní ekonomiky.

Sayův koncept tří výrobních faktorů byl definován před prezentací Marxova ekonomického modelu, v němž Marx mj. podal kritiku J. B. Saye, která se opírala o to, že nerozlišuje užitnou hodnotu a hodnotu zboží. ${ }^{35}$ Ve své podstatě však cíl kritiky spočíval pouze v orientaci Marxova ekonomického učení na teorii nadhodnoty, kterou dokázal vysvětlit pouze na teoretickém konceptu práce produktivní, která vytváří zboží jako „ekonomickou buňku kapitalismu“.

\section{Teorie lidského kapitálu v dimenzi pomáhajících profesích}

Téměř každý člověk je schopen pracovat, ale kvalita a množství práce každého jednotlivce je determinována jeho fyzickými a duševními schopnostmi. Za účelem výkladu rozdílnosti jedinců v rámci pracovní činnosti lze aplikovat teorii lidského kapitálu. Ta je založena na investicích do lidských zdrojů při vytváření kvalifikačních schopností, do upevňování zdraví a všestranné kvality života. Ze své podstaty představuje lidský kapitál produktivní schopnosti jedince. Toto pojetí je chápáno jako základní lidský kapitál. V širším pojetí jde o potenciál rozvíjet a uplatňovat své schopnosti. Datovat počátky teorie lidského kapitálu lze v myšlenkovém prostředí chicagské

34 Srov. tamtéž, s. 40.

35 Srov. Karel MARX, Ke kritice politické ekonomie, Praha: Státní nakladatelství politické literatury, 1953, s. 19-24. 
ekonomické školy počátkem 50 . let 20 . století. Tato škola přišla s rozlišením bohatství společnosti na lidský a nikoli-lidský kapitál. ${ }^{36}$ Duchovním otcem této teorie byla významná osobnost světové monetaristické teorie profesor Milton Friedman (v roce 1976 oceněn Nobelovou cenou za ekonomii). Teoretický koncept $M$. Friedmana detailně rozpracoval jeho žák rovněž z chicagské školy Gary Stanley Becker (v roce 1992 oceněn Nobelovou cenou za ekonomii). Beckerův př́stup je striktně ekonomický, nebot východiska veškerého lidského chování spočívají z principu racionální volby na bázi maximalizace užitku ze stabilního souboru preferencí. Ve své podstatě se jedná o zobecnění a mikroanalýzu racionality ekonomického člověka, resp. přenesení tohoto principu také do sféry mimotržních subjektů a situací či vztahů. Na člověka nahlíží G. S. Becker primárně jako na "homo oeconomicus “, 37 tvrdí, že ekonomie se neliší od jiných věd předmětem zkoumání, ale prrístupem ke zkoumání člověka. Zejména díky Beckerovi začala ekonomie zasahovat do oblastí společenských věd - etiky, psychologie, sociologie, kriminologie či demografie, čímž získala pozici vědy „imperiálnî ${ }^{\text {“ } 38}$

G. S. Becker navíc rozdělil lidský kapitál na dvě kapitálové složky, kterými byly osobní a společenský kapitál. Osobní kapitál je zároveň determinován zásobami „Zvykového“a „představivostního“.39 Beckerova teoretická analýza lidského kapitálu vychází z reality, že každý jedinec je téměř univerzální spotřebitel. Výše jeho spotřeby je dána důchodem, zatímco její orientace vychází z jeho preferencí. Ty jsou dány patřičnou konstituční a psychologickou typologií osobnosti, sociálním prostředím a zvyky. Je zřejmé, že každý jedinec se nerodí jako „nepopsaný list“, spíše přichází na svět s omezenými zkušenostmi, které rozvijí v dětství a ve svém pozděǰsím vývoji. Tyto zkušenosti ovlivňují touhy a volby dospívajících i dospělých částečně vytvářením zvyků, návyků a tradic. Za druhou „představivostni“ zásobu osobního kapitálu G. S. Becker označuje trénovanou schopnost jedince nepodhodnocovat budoucnost, což mu napomáhá lépe ocenit budoucí užitky. ${ }^{40}$ Vzhledem k tomu, že teorie redistribučního systému hledá cesty, jak „dešifrovat“ chování člověka, mohla by pomoci rozvíjet právě tuto složku kapitálu. Právě představivost v širších souvislostech, jakýsi nadhled nad chováním jak vlastním, tak ostatních lidí může být dobrým vstupním kapitálem do života.

Sociální kapitál pak určuje vliv preferencí ostatních osob v jedincově sociálním prostředí. Vzestup společenského kapitálu může jedincův užitek zvýšit nebo snižit. To lze interpretovat na modelovém př́kladu, kdy tlak referenční skupiny na dospívajícího, aby začal s kvalitním životním stylem, zvyšuje jeho užitek a jeho závislost na chování druhých může vytvářet různé externality pozitivní povahy. ${ }^{41}$

Z výše uvedených důvodů je zcela jisté, jaké budou projevy úrovně lidského kapitálu pomáhajících profesí na lidský kapitál jejich klientů a následně na kvalitě života celé společnosti. $\mathrm{V}$ tom lze spatřovat jistý „,irkulárni“ pohyb - koloběh, jehož podstatu výkladu lze aplikovat prostřednictví teorie chování sociálních systémů, a to prostřednictvím systémové dynamiky, formované od poloviny minulého století Jayem Forresterem, nebo synergetikou, datovanou od roku 1984. V obou př́padech lze dospět ke stejnému závěru, kterým je požadovaná kvalita lidských zdrojů

36 Srov. Gary Stanley BECKER, Investment in Human Capital: A Theoretical Analysis. Investment in Human Beings, Journal of Political Economy 5(2)/1962, s. 9-49.

37 Gary Stanley BECKER, Human Capital: A Theoretical and Empirical Analysis, with Special Reference to Education, Third Edition, Chicago: The University of Chicago Press, 1993, s. 390.

38 Gary Stanley BECKER, Teorie preferencí, Praha: Liberální institut/Grada Publishing, 1997, s. 350.

39 Tamtéž, s. 17.

40 Srov. tamtéž, s. 43.

41 Srov. tamtéž, s. 36. 
jako vnitřní síla k zajištění dlouhodobého stabilního ekonomického růstu. ${ }^{42}$ To je plně v souladu s teoretickými koncepty endogenního růstu formovanými v 80. letech minulého století Robertem Lucasem a Paulem Romerem. Je dokázáno, jakou významnou vnitřní sílu ekonomiky představují lidské zdroje. ${ }^{43} \mathrm{~V}$ tom lze také spatřovat opodstatněnost významu investic na všestrannou podporu kvality lidského života. Významnou složkou těchto investic je právě již zmíněná činnost pomáhajících profesí ve společnosti.

V duchu teoretických konceptů lidského a sociálního kapitálu je pomáhající profesionál jedinec, který má patřičné zkušenosti, př́islušnost v jasně stanovené organizaci, ve které nese důležitou zodpovědnost. Tedy zkušenosti, příslušnost k organizaci a zodpovědnost jsou tím, čím se odlišuje profesionál od ostatních. ${ }^{44}$ Zkušenost se získává specializovaným vzděláním a dlouhou praxí. Ovšem vzdělání a praxe nejsou zpravidla přístupné laikům, tj. těm, kdo nepatří do profese. Příslušnost je součástí i zárukou toho, že člověk funguje jako právoplatný a spolehlivý člen organizace a pro tyto účely se udržuje, a to zcela vědomě prostřednictvím zvyšováním kvalifikace. Zodpovědnost pak vzniká coby důsledek důležitosti profesní služby, kterou profesionál dává jiným.

\section{Ekonomické aspekty v kontextu aktuálních výzev pro pomáhající profese}

Oprávněně se přiřazuje pomáhající profesi vznešenost, čímž lze označit její ušlechtilost a cosi dokonalejšího a velmi seriozního. Pomáhající profese má co do činění s lidmi. Z toho vyplývají i patřičné požadavky na personál těchto profesí, kdy se k hlavním prioritám řadí důkladné znalosti o lidských hodnotách, o tom, co lidi motivuje, o problematice lidského chování, o morálce a s ní spojených hodnotách. Vzdělání v humanitních a společenských vědách je naprostou nezbytností a předpokladem dalšího profesionálního růstu. Kvalifikace pomáhajícího profesionála není jen jakousi mechanickou dovedností ani „uměním“, které vyžaduje talent, ale je to výsledek kombinace studia společenských a humanitních věd, které stimulují myšlení, studia specializovaných předmětů jeho profese, ale zároveň i následné odborné praxe v pomáhajícím oboru. Kvalifikace pomáhajícího pracovníka tedy vyžaduje celostní nepřetržité vzdělávání. To mimo jiné vyžaduje i nástup Průmyslu 4.0, který se rovněž dotkne změn stylu a organizace práce pomáhajících profesí. V této souvislosti změn (jako je trend digitalizace, robotizace, automatizace, umělé inteligence...) lze také hovořit o formování Pomáhajících profesí 4.0. Je to logické, nebot s inovacemi nových technologií budou spojeny celé řady sociálních problémů, které přispějí k nežádoucí až urychlené „amortizaci“ lidského kapitálu některých sociálních skupin obyvatelstva - obdobně jako v minulosti vždy inovace nových technologií přinášely nezaměstnanost pro určité skupiny osob, které se nebyly schopny adaptovat na nové trendy v pracovním procesu. V této souvislosti pomáhající profese napomohou s nalezením odpovídajícího pracovního uplatnění, popřípadě formou odborného poradenství zredukují nežádoucí dopady na nezaměstnaného a jeho nejbližší sociální okolí, kterým je rodina. Zároveň působí v rámci sociální ekonomiky jako převodové páky mezi managementem sociální firmy a zaměstnancem se specifickými potřebami. Navíc v rámci Průmyslu 4.0 nastávají z hlediska adiktologie potenciální rizika nových forem neřestí v podobě závislostí s přívlastky „digitální, elektronické“ apod. Bude opět na pomáhajících profesích nastavit terapie a metody sociální práce pro pomoc obětem závislostí na „elektronických drogách“. Zároveň je nastupující éra Průmyslu 4.0 v České republice, stejně jako v ostatních evropských

42 Srov. Robert LUCAS, On the Mechanics of Economic Development, Journal of Monetary Economics 22/1988, s. 3-39.

43 Srov. Paul ROMER, Increasing Returns and Long-Run Growth, Journal of Political Economy 5/1986, s. 1002-1037.

44 Srov. Angela BARON - Michael ARMSTRONG, Human Capital Management: Achieving Added Value Through People, London: Kogan Page Publishers, 2007, s. 240. 
státech, provázena procesem stárnutí populace s mnoha ekonomickými a sociálními změnami. Je logické, že starší skupiny obyvatel potřebují zvláštní péči, a proto lze také očekávat růst poptávky po službách pomáhajících profesí v oblasti gerontologie. Je téměř jisté, že ke značné akceleraci poptávkového růstu nastane po roce 2035, kdy začnou do penze odcházet značně silné ročníky 70. let 20. století (díky propopulační politice se v 70. letech 20. století rodilo ročně v průměru 190 tisíc dètí, vrcholu bylo dosaženo v roce 1974, kdy se narodilo 194215 živých dètí). ${ }^{45}$ Lze tedy po roce 2035 očekávat akceleraci růstu sociální skupiny seniorů. ${ }^{46} \mathrm{Na}$ straně druhé trend poklesu počtu obyvatel v produktivním věku (zhruba o $40 \%$ do konce roku 2100) se jednoznačně projeví v makroekonomických a mikroekonomických dopadech. ${ }^{47}$

Na základě výše uvedené demografické prognózy s tím budou rovněž souviset i patřičné reformní procesy v systému a organizaci práce pomáhajících profesí. V rámci podpory uvedené reformy je nezbytné aplikovat princip subsidiarity, a to služeb v oblasti gerontologie. Bez ohledu na ekonomické a sociální dopady stárnutí populace lze konstatovat, že senioři představují sociální skupinu obyvatelstva diferencovanou řadou faktorů, ke kterým se řadí zdraví, rodinné vztahy, inteligence, životní styl, vzdělání, etnický původ, náboženské vyznání, socioekonomický status. Uvedené faktory jsou důvodem pro rozdílnou aplikaci pomáhajících profesí pro zmíněnou sociální skupinu obyvatelstva. $Z$ tohoto důvodu by se jevilo jako zcela logické v rámci respektování ekonomické efektivnosti zpracovat model chování a plánování lidských zdrojů pomáhajících profesí v oblasti gerontologie. Pro zpracování modelu lze aplikovat klouzavý př́stup, tj. pružné aktuální přizpůsobení veškerým změnám systémového okolí (dynamice právních norem a aplikaci zavádění Technologií 4.0) v poskytování sociálních služeb, a to na časový horizont 10 let. Výstupním dokumentem by byl návrh programu Plánu lidských zdrojů na poskytování sociálních služeb $\mathrm{v}$ oblasti gerontologie na zmíněný časový horizont. Ve své podstatě by se jednalo o komplexní plán na makroúrovni. Při zpracování bude aplikována metoda systémové dynamiky s patřičnými simulacemi na základě vstupních proměnných (tj. dokumenty Českého statistického úřadu o demografickém vývoji obyvatelstva, rezortů zdravotnictví, práce a sociálních věcí, školství...). Lze předpokládat, že koncovými uživateli tohoto programu budou zejména orgány zainteresovaných ministerstev (práce a sociálních věcí, školství mládeže a tělovýchovy, zdravotnictví...), Asociace poskytovatelů sociálních služeb, popřípadě další participující instituce státní správy, samosprávy a nestátních neziskových organizací. Na základě takto získaných informací by se vytvořily podmínky pro patřičná strategická rozhodnutí a opatření pro orientaci pomáhajících profesí v oblasti gerontologie. Značně by se zredukovalo potenciální riziko nedostupnosti některých těchto specifických služeb v rámci města, obce, regionu.

\section{Závěr}

Zhruba od poslední třetiny minulého století v rozvinutých tržních ekonomikách značně akceleruje trend orientace na dimenzi lidského faktoru. Paralelně se v tomto období rozvíjí již zmíněná teorie lidského a sociálního kapitálu. Výsledkem interdisciplinárního př́stupu společenských a humanitních věd, kybernetiky a manažerských teorií vznikly mezní obory, na základě jejichž

45 Srov. Renata KLUFOVÁ - Zuzana POLÁKOVÁ, Demografické metody a analýzy, demografie České a Slovenské populace, Praha: Wolters Kluver ČR a.s., 2010, s. 248.

46 Srov. () Ministerstvo práce a sociálních věcí: Evropský rok aktivního stárnutí a mezigenerační solidarity (2012) v České republice [online]. Dostupné na:https://www.mpsv.cz/cs/11696, citováno dne 26. 11. 2017.

47 Srov. Tomáš PAVELKA, Long-term unemployment in the Czech Republic and the effect of distraints, $11^{\text {th }}$ International Days of Statistics and Economics, Praha, Czech Republic, 2017, s. 1153-1162. 
teoretických konceptů se vytvořily a rozvíjí i zcela nové specializace pomáhajících profesionálů. Společným znakem těchto uvedených profesí je orientace na člověka, různé zájmové skupiny, mezilidské vztahy apod. Typickým př́kladem jsou sociální pracovníci při práci s jedincem či komunitou. Specifická provázanost těchto profesí se projevuje v tom, že tyto úzce zaměřené oblasti jsou doménou specializací odborníků pro každodenní náplň činností požadovaného standardu kvality života. Je to logické, nebot přes veškeré problémy ekonomické, redukční, reorganizační a finanční je $\mathrm{v}$ konečném efektu ústředním bodem a problémem člověk. Ten celý proces řídí, realizuje a konečný výsledek je určen pro něho, od jeho kvality života se důsledkem synergetického efektu odvíjí i ekonomický růst jako součást národního bohatství. To rovněž dokládá výše uvedená teorie endogenního růstu podle R. Lucase a $\mathrm{P}$. Romera. Zmíněná teorie vychází z empirické analýzy založené na korelaci investic do lidských zdrojů pro podporu ekonomického růstu. V kontextu s touto teorií představují pomáhající profesionálové vnitřní sílu ekonomiky pro zajištění jejího růstu.

Přestože pomáhající profese jsou zdrojem pro stabilní ekonomický růst, jejich ocenění na trhu práce, zejména sociálních pracovníků a pracovníků v sociálních službách, je pod úrovní průměrné mzdy $\mathrm{v}$ národním hospodářství. $\mathrm{V}$ této souvislosti se při zpracování hledala odpověd’ na otázku, jaká je motivace působit jako pomáhající profesionál. Jednou z možných verzí odpovědi lze právě hledat $\mathrm{v}$ provázanosti teorii lidského a sociálního kapitálu, a to právě prostřednictvím zvyků, tradic z rodinného prostředí, psychologickou typologií osobnosti apod. Důsledkem těchto faktorů je tak u pomáhajících profesionálů „vypěstovaný duch“ pomáhat potřebným v jejich tíživé situaci. Obdobná situace je také u dobrovolníků působících v sociální sféře.

\section{Kontakt na autora}

Ing. Jaroslav Šetek, Ph.D.

Jihočeská univerzita v Českých Budějovicích

Ekonomická fakulta, Katedra ekonomiky

Studentská 13, 37005 České Budějovice

jsetek@ef.jcu.cz 